\title{
ENVIRONMENTAL POLLUTION BY WASTEWATER FROM BROWN COAL PROCESSING - A REMEDIATION CASE STUDY IN GERMANY
}

\author{
Arndt Wiessner ${ }^{\mathrm{a}}$, Jochen A. Müller ${ }^{\mathrm{a}}$, Peter Kuschk ${ }^{\mathrm{a}}$, Uwe Kappelmeyer ${ }^{\mathrm{a}}$, Matthias Kästner ${ }^{\mathrm{a}}$, \\ Yong-Jun Liu ${ }^{\mathrm{b}}$, Ulrich Stottmeister ${ }^{\mathrm{a}}$ \\ ${ }^{a}$ UFZ-Helmholtz Centre for Environmental Research, Permoserstrasse. 15, D-04318 Leipzig, Germany \\ ${ }^{b}$ Key Laboratory of Northwest Water Resource, Ecology and Environment, Ministry of Education, \\ Xi'an University of Architecture \& Technology, Xi'an, China \\ Submitted 3 May 2012; accepted 11 May 2013
}

\begin{abstract}
The large scale of the contamination by the former carbo-chemical industry in Germany requires new and often interdisciplinary approaches for performing an economically sustainable remediation. For example, a highly toxic and dark-colored phenolic wastewater from a lignite pyrolysis factory was filled into a former open-cast pit, forming a large wastewater disposal pond. This caused an extensive environmental pollution, calling for an ecologically and economically acceptable strategy for remediation. Laboratory-scale investigations and pilot-scale tests were carried out. The result was the development of a strategy for an implementation of full-scale enhanced in situ natural attenuation on the basis of separate habitats in a meromictic pond. Long-term monitoring of the chemical and biological dynamics of the pond demonstrates the metamorphosis of a former highly polluted industrial waste deposition into a nature-integrated ecosystem with reduced danger for the environment, and confirmed the strategy for the chosen remediation management.
\end{abstract}

Keywords: disposal pond, environmental pollution, lignite pyrolysis, remediation strategy, wastewater.

Reference to this paper should be made as follows: Wiessner, A.; Müller, J. A.; Kuschk, P.; Kappelmeyer, U.; Kästner, M.; Liu, Y.-J.; Stottmeister, U. 2014. Environmental pollution by wastewater from brown coal processing - a remediation case study in Germany, Journal of Environmental Engineering and Landscape Management 22(1): 71-83. http://dx.doi. org/10.3846/16486897.2013.808640

\section{Introduction}

\section{Extent of brown coal mining and processing in Central Germany}

The mining of lignite and the subsequent processing for the chemical industry has a long history in several countries of the world. These activities have produced relics of different quality and magnitude. In contrast to engineering reports in technical bulletins, there are only few scientific publications about the remediation of contaminated sites by this industry in peer-reviewed journals (Stottmeister et al. 2009; Kubal et al. 2011). Because of the increasing price for oil, carbon/lignite chemistry will probably experience a renaissance (Volkmann, Borner 2012; Zhou et al. 2012). This assumption is supported by an increasing number of publications about the processing of lignite for the chemical industry (Tokarska 2009; Ciahotny et al. 2011). This article not only summarizes the history of environmental problems caused by this industry using the example of Germany with the intention of providing environmental engineers with an idea of consequences when wastes are not handled in a proper way, but also includes suggestions of how to manage these problems.

From the middle of the nineteenth century until the reunification of Germany in 1990 the central regions of Germany were characterized by extensive brown coal mining. The areas particularly around Böhlen, Espenhain, Altenburg, Zeitz, Bitterfeld, Wolfen, and Leuna-Buna near the cities of Leipzig and Halle were dominated by large-scale open-cast mining (Stottmeister et al. 1997).

Massive exhausting (subrosion of anhydrite) during the Tertiary Period caused the formation of mighty basins within the marine Zechstein and Sandstone from the early Triassic epoch. In the Eocene and Oligocene epochs, these basins were filled with brown coal, forming altogether four seams of different mightiness and quality of the lignite (Eissmann 1994). The oldest seam in the south of Leipzig was 
raised by sedimentation of a hydrodynamic bog and the lignite was found to have a high content of bitumen suitable for coking and applications in chemical industries. Newer seams are characterized by a high load of xylite suitable for energy production.

Brown coal mining started in the middle of the nineteenth century near the cities of Weißenfels and Zeitz. From the middle of the 1930s, on the basis of lignite carbon-chemical industries were growing in Central Germany. The German Democratic Republic (GDR) became the world's largest producer of lignite due to a lack of alternative raw materials for the production of energy and chemicals (Stottmeister et al. 1997, 2009; Bilkenroth, Snyder 1998). In 1985, approximately 310 million tons or $28 \%$ of the worldwide total brown coal production was mined in 33 open-cast mines in the GDR (Stottmeister et al. 1997). Nearly $70 \%$ of the lignite was directly burned for energy production (electrical power) and 30\% was used for the production of briquettes (Stottmeister et al. 2002). About $92 \%$ of the briquettes were used for house heating and $8 \%$ for the carbon-chemical industries (Stottmeister et al. 2002). The main processes of the carbo-chemical industries were carbonization, coking, gasification and hydrogenation for producing coke, synthesis gas, fuel, tar, oil, wax and several basic chemicals, such as benzene, ammonia and sulphuric acid (Ringpfeil et al. 1988).

The demand for brown coal drastically decreased in the years after the reunification of Germany. Nowadays lignite is of subordinated importance but is still used, to a lesser extent, by modernized or modern power stations for the production of electrical power. The economically inefficient carbo-chemical industries of the former GDR were completely discontinued in the Central German territories.

\section{Environmental consequences of long-term brown coal mining and processing in the Central German territories}

\subsection{Extent of environmental pollution}

The extensive brown coal mining in the Central German regions caused enormous environmental damages, such as landscape destruction and pollution, exhaust gas pollution, as well as pollution of rivers and lakes from wastewaters and solid wastes (Stottmeister et al. 2002).

Most of the technical equipment installed in the 1920s and the 1930s in the industrial centres went out of date years ago, but was still used until their closure in the early 1990s. In some cases, provisional reconstruction of massive damages during World War II remained the state of the art. Dangerous wastes from industrial processing, such as tars, wastewaters from lignite pyrolyses, and so on, were usually released untreated and often uncontrolled into the environment (Stottmeister et al. 1997, 2002).
The whole territory of the lignite deposits of Central Germany was characterized by many opencast mines. For example, an area with a length of approximately $90 \mathrm{~km}$ north/south and $30 \mathrm{~km}$ east/west enclosing the city of Leipzig was extensively used for brown coal mining. Nearly one-third of the territory south of Leipzig was considered to be a so-called postmining area (Stottmeister et al. 1997). Former opencast mines and other areas transformed by extensive mining were normally used for the disposal of all kinds of wastes from mining, industries and households, resulting in an imminently dangerous contamination of groundwater and/or air of the related districts (Stottmeister et al. 1999).

Finally, after the termination of extensive mining and processing in the early 1990s, a total of 570 suspicious areas with dangerous wastes from the past were found in these regions. Exactly 327 of them were remediated by 2002, and for 128 no treatment was considered necessary. However, in 2002, 115 suspicious areas were found to be still untreated and 30 of them were regarded dangerous and in need of urgent remediation (Stottmeister et al. 2002).

In general, the single depots of dangerous wastes of the past typically have unique site characteristics and require defined remediation strategies related to the prevailing pollution. Irrespective of the particular site characteristics, focus is on prevention of gas emissions into the air and protection of the water resources, and so on.

\subsection{Environmental pollution due to wastewater from lignite pyrolysis}

The extensive lignite pyrolysis, such as coking, gasification, hydrogenation or low-temperature carbonization, had led to a widespread generation of highly polluted wastewater. This wastewater resulted from the heating of the brown coal, whereby large amounts of water steam originated from the thermal reactions and the release of the bounded water from within the coal. As an example, the mass balance of coking briquettes for producing gas, oil and formed coke is presented in Table 1.

In this way, nearly one-fourth of the initial mass was transformed into wastewater. The water steam

Table 1. Mass balance of coking brown coal briquettes (Stottmeister 2008)

Coking of $1000 \mathrm{~kg}$ of brown coal briquettes resulted in the formation of:

\begin{tabular}{lr}
\hline Coke & $431.4 \mathrm{~kg}$ \\
Gas & $262.6 \mathrm{~kg}$ \\
Tar & $58.1 \mathrm{~kg}$ \\
Reaction water & $91.9 \mathrm{~kg}$ \\
Inherent water & $156.0 \mathrm{~kg}$ \\
\hline
\end{tabular}


produced during these processes contained lowmolecular phenolics and fatty acids, as well as hydrogen sulphide and ammonia. The composition and the amounts typical for the wastewater generated from brown coal of the Central German mining territories are given in Table 2.

Among the polyhydric phenols (polyphenolic compounds) were detected catechol, resorcinol, hydrochinone and pyrogallol and their derivatives (Stottmeister 2008). Usually, the condensed waters from the generated steam were of light red color and the $\mathrm{pH}$ was in the range of 7.5 to 10 (Ringpfeil et al. 1988). Caused by the air oxygen, the color of the condensate turned to dark brown over time due to autoxidation of aromatic compounds, as seen with phenolic derivatives forming polymeric molecules (Kuschk et al. 2010). These generated artificial fulvic/humic substances are known to be highly resistant to microbial degradation (Wießner et al. 1994; Kopinke et al. 1995a, b; Pörschmann et al. 1998a). The polymerization by autoxidation in such wastewater also involves nitrogen and sulphur compounds, but does not involve any aliphatic fatty acids (Stottmeister 2008). In this way, the long-term disposal of such wastewater in abandoned open-cast mines resulted in the formation of colloid structures and finally in suspended solid particles formed by the aggregation of the humic macromolecules (Wießner et al. 1993; Stottmeister 2008). The reactivity of the dissolved and colloidal or solid suspended humic substances in the deposited wastewater is partly comparable to soils in respect to the incorporation of contaminants, masking of smaller molecules, and so on (Pörschmann et al. 1996, 1997, 1998a, b; Mackenzie et al. 2002). The disappearance of low-molecular fatty acids and the unchanged high ammonia concentrations were usually observed in wastewater from lignite pyrolysis being stored in derelict open-cast-mines for a long time. Importantly, the toxicity of the water probably reduced the longterm efficiency of microbial degradation of contaminants (Wießner et al. 1993; Stottmeister et al. 1997).

However, the insufficiently treated (Table 3) and, in occasional cases, even untreated wastewater was released into the environment such as rivers, lakes, unused fallow land, and former open-cast mines for disposal or seepage (Stottmeister et al. 1999; Eccarius et al. 2001). In some cases, the wastewater was pumped into the deep layers of the Upper Permian Zechstein (Eccarius 1998). The long-term input of the wastewater into abandoned open-cast mines resulted in the formation of large ponds with a significant potential environmental danger particularly for groundwater and the human population of the surrounding areas (Eccarius 1998).

\subsection{Perspectives of large-scale environmental problems and sustainable development}

The importance of coal mining and processing is still high nowadays due to the drastically increasing needs of energy and raw materials worldwide (Biswas et al. 2010; Thiruvenkatachari et al. 2011; Zhang et al. 2011). Particularly in countries such as China, India, Brazil, and Australia with a rapidly accelerating energy demand and enhanced coal mining/industries, the related environmental problems are still acute and have sparked a search for new solutions regarding wastewater problems (Domazetis et al. 2010; Huang et al. 2010). Those novel approaches target environmental issues associated with classical coal processing such as combustion, coking, and gasification, as well as new coal applications, such as pyrolysis of sludges and extraction of rare elements (Folgueras, Diaz 2010; Zhang et al. 2011; Wu et al. 2012;). Similar treatment technologies may be applicable to wastewater problems caused by hydrothermal dewatering of peat, wet air oxidation of black liquor, petroleum refineries and other industries (Garg et al. 2008; Tomei, Annesini 2008; Mursito et al. 2010).

Moreover, increasing traffic worldwide causes large-scale environmental problems (Baltrenas, Kazlauskiene 2009; Valentukeviciene, Ignatavicius 2011). In general, all of these environmental waste problems may concern grounds and diverse water bodies such as groundwater, rivers, lakes and stored wastewater inside abandoned coal mines, ponds and lakes and research

Table 2. Composition of phenolic waters from brown coal carbonization, gasification, and tar hydrogenation (Ringpfeil et al. 1988)

\begin{tabular}{|c|c|c|c|c|c|c|}
\hline & \multicolumn{2}{|c|}{ Carbonization } & \multirow[b]{2}{*}{$\begin{array}{c}\text { Tar } \\
\text { distillation } \\
(\mathrm{g} / \mathrm{l})\end{array}$} & \multirow[b]{2}{*}{$\begin{array}{c}\text { Washing oil } \\
\text { distillation water } \\
(\mathrm{g} / \mathrm{l})\end{array}$} & \multirow[b]{2}{*}{$\begin{array}{c}\text { Gasoline } \\
\text { distillation water } \\
(\mathrm{g} / \mathrm{l})\end{array}$} & \multirow[b]{2}{*}{$\begin{array}{c}\text { Phenosolvan } \\
\text { weak gas liquor } \\
(\mathrm{g} / \mathrm{l})\end{array}$} \\
\hline & $\begin{array}{l}\text { Gas liquor } \\
(\mathrm{g} / \mathrm{l})\end{array}$ & $\begin{array}{l}\text { Liquor } \\
(\mathrm{g} / 1)\end{array}$ & & & & \\
\hline Monohydric phenols & 4.2 & 9.9 & 18.7 & 2.0 & 4.7 & \\
\hline Polyhydric phenols & 4.6 & 8.3 & 4.0 & 7.5 & 6.5 & 2.2 \\
\hline Fatty acids & 2.0 & 9.9 & 3.8 & 3.5 & 4.4 & 5.6 \\
\hline $\mathrm{H}_{2} \mathrm{~S}$ & 0.3 & 0.5 & 0.2 & 8.5 & 6.0 & \\
\hline $\mathrm{NH}_{3}$ & 4.6 & 5.1 & 1.8 & 19.8 & 13.5 & 4.9 \\
\hline
\end{tabular}


Table 3. Efficiency of the treatment of wastewater from brown coal processing using a bio-tank reactor (Ringpfeil et al. 1988)

\begin{tabular}{lcc}
\hline & $\begin{array}{c}\text { Inlet concentration } \\
(\mathrm{mg} / \mathrm{l})\end{array}$ & $\begin{array}{c}\text { Degradation } \\
\text { efficiency }(\%)\end{array}$ \\
\hline $\mathrm{BOD}_{5}$ & $2000-12,000$ & 85 \\
$\mathrm{NH}_{4}^{+}-\mathrm{N}$ & $500-3.000$ & 35 \\
Volatile phenols & $50-600$ & 99 \\
Volatile fatty acids & $1000-2,000$ & 90 \\
Formaldehyde & $1000-3,000$ & 45 \\
\hline
\end{tabular}

for sustainable ecological development is in progress and has to be intensified (Pathiratne et al. 2007; Baltrenas, Kazlauskiene 2009; Xu et al. 2010; Qi et al. 2011; Valentukeviciene, Ignatavicius 2011). Research and technological expertise as documented in this paper may be helpful to find solutions for the remediation of environmental pollution by coal and related industries.

\section{Large-scale remediation of a phenolic wastewater disposal pond - a case study}

\subsection{Characterization of the wastewater pond}

The so-called "phenol lake" Vollert-Süd was a former open-cast lignite mine in which highly polluted wastewater was discharged from a near low-temperature coking plant between 1950 and 1968. The disposal pond is located in the state of Saxony-Anhalt in Germany (N51 $06^{\prime} 15.8^{\prime \prime}$, E12 $03^{\prime} 28.0^{\prime \prime}$, WGS84). It has an oval surface shape, a surface area of nearly 9 ha, a maximum depth of $27 \mathrm{~m}$ and contains approximately 2 million $\mathrm{m}^{3}$ water (Wießner et al. 1993; Kuschk et al. 1994; Stottmeister et al. 1998, 1999). The geometrical data of the pond were measured by echograph (Table 4).

The sediment layer at the bottom of the pond was measured to be $0.1 \mathrm{~m}$ thick at the edges and had a maximum of $1.2 \mathrm{~m}$ in the centre. The transparency of the deeply dark brownish colored water, which was free of dissolved oxygen, was only about $3 \mathrm{~cm}$ (Wießner et al. 1993; Stottmeister et al. 2002).

Table 4. Relation between the depth and the resulting theoretical surface area of the disposal pond (Stottmeister et al. 2009)

\begin{tabular}{lc}
\hline Depth $(\mathrm{m})$ & Theoretical surface area $(\%)$ \\
\hline 0 & 100 \\
10 & 40 \\
15 & 22 \\
20 & 22 \\
24 & 11 \\
25 & 5 \\
\hline
\end{tabular}

Phenolic compounds and ammonium were found to be the highest concentrated contaminants of the water dependent on the depth of the pond, as shown in Figure 1.

The phenol, ammonium and COD concentrations increased up to a depth of approximately $15 \mathrm{~m}$ before reaching a constantly high level in the lower layers of the water body. The composition of the specific phenolic loads, $n$-alkanes and further alcohols were analyzed in the water from a depth of $24 \mathrm{~m}$. The results are listed in Table 5.

Altogether, more than 100 different organic compounds were detected using thermoanalytical methods. In this way, several polycyclic aromatic hydrocarbons (PAHs) were determined in the water body and the sediment of the pond. For instance, the naphthalene concentration in the water amounted to $0.13 \mu \mathrm{g} / 1$ on the surface and $210 \mu \mathrm{g} / \mathrm{l}$ at a depth of $24 \mathrm{~m}$. In the sediment at the centre of the disposal pond, the concentration reached even $30 \mathrm{mg} / \mathrm{kg}$ (Wießner et al. 1993).

Water from the surface layer and at a depth of $24 \mathrm{~m}$ was investigated by micro- and ultrafiltration in relation to the dissolved organic carbon (DOC) to evaluate the molecular size distribution of the organic compounds (Fig. 2; Table 5).

The total organic load of the deep water was found to be higher compared to the surface water. Approximately one half of the total DOC-load of this deep water was in the low-molecular range of $<0.5 \mathrm{kDa}$ and the remainder was almost similarly distributed in the higher molecular, colloidal or particular ranges. In contrast, in the surface water, the organics were similarly distributed involving all ranges and only $16 \%$ of the total amount was found to be in the lowmolecular range of $<0.5 \mathrm{kDa}$. These results reveal the efficiency of auto-oxidative polymerization of lower molecules up to certain ranges forming artificial fulvic/ humic compounds (Pörschmann, Stottmeister 1993; Wießner et al. 1994; Kopinke et al. 1995a, b; Stottmeister 2008). Furthermore, the removal of the organic load by physical/chemical and biological processes

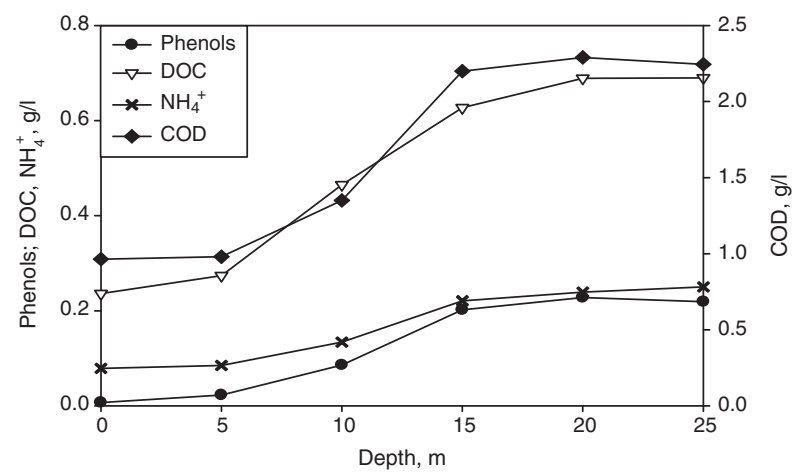

Fig. 1. Analytical data of the disposal pond water depending on the depth before remediation (Wießner et al. 1993) 


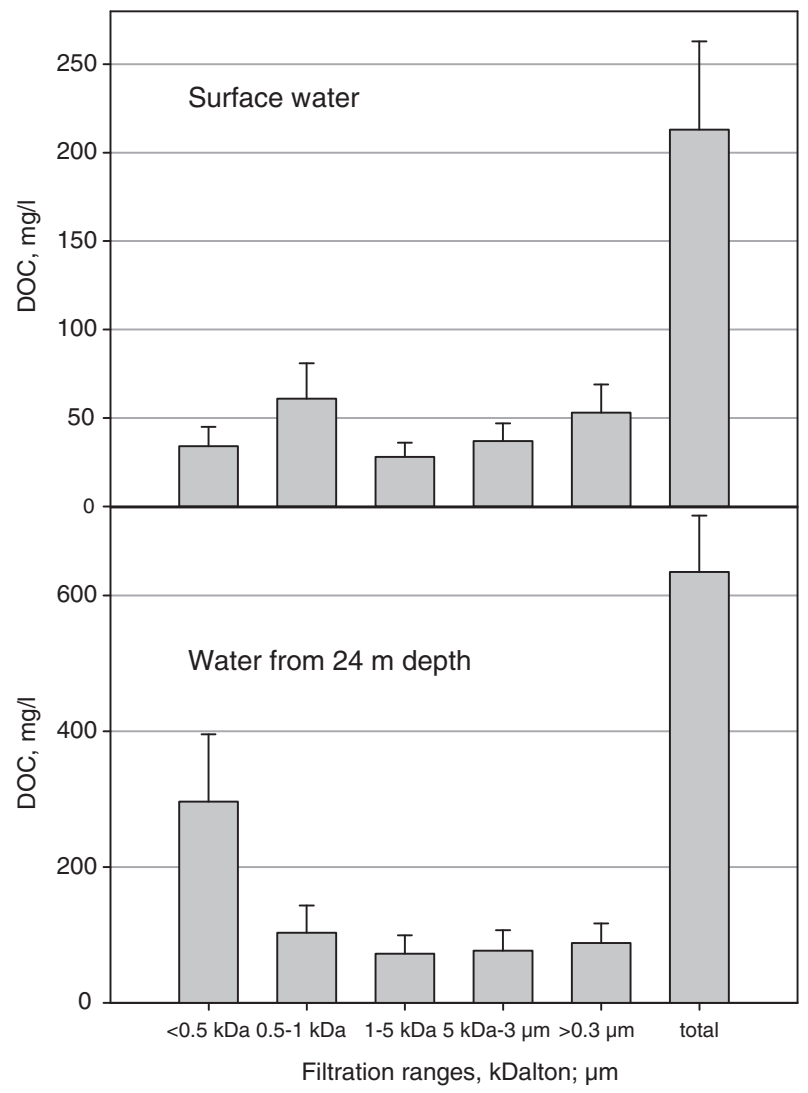

Fig. 2. Molecular size distribution of the DOC in the wastewater disposal pond "Vollert-Süd" before remediation

within the upper layer of the disposal pond (by autooxidation, sedimentation, degradation) was confirmed. Toxicity of water from different depths and for all filtration ranges was estimated using the Photobacterium-test (Wießner et al. 1993; Stottmeister et al. 1997). Accordingly, the surface water of the pond was found to be fivefold more toxic than the water contaminated with pure phenol of a similar DOC concentration. The highest toxicity was estimated for the fraction of $<0.5 \mathrm{kDa}$ of the surface water. The results indicate a comparably higher toxic efficiency of alkylphenols and/or higher molecular auto-oxidation products of phenolic compounds. Nevertheless, high concentrations of microorganisms were detected at all depths

Table 5. Analytically detectable main monomeric compounds of the water of the disposal pond at a depth of $24 \mathrm{~m}$ (Wießner et al. 1993)

\begin{tabular}{llc}
\hline Group & \multicolumn{1}{c}{ Compound } & Concentration $(\mathrm{mg} / \mathrm{l})$ \\
\hline Phenols & Phenol & 135 \\
& $m$-Cresol & 22 \\
& $p$-Cresol & 57 \\
& Sum of $\mathrm{C}_{2}$-phenols & 53 \\
& Sum of $\mathrm{C}_{3}$-phenols & 20 \\
& Sum of $\mathrm{C}_{4}$-phenols & 7 \\
n-Alkanes & $\mathrm{C}_{10} \ldots \mathrm{C}_{42}$ & 210 \\
\hline
\end{tabular}

of the water body. The mean numbers of living bacterial cells per $\mathrm{ml}$ were found to range from $4 \times 10^{4}$ in the water at a depth of $24 \mathrm{~m}$ to $2 \times 10^{6}$ in the surface water (Stottmeister et al. 2002). Apparently, the relevant microorganisms were well adapted to these conditions.

The removal of organics from the upper layer of the disposal pond should be facilitated by atmospheric oxygen. Consequently, the seasonal dynamics of the water body was investigated, and the disposal pond was found to behave as a meromictic water body with seasonal changes in the water density, the stratification, and the mixing due to wind and waves influenced by the specific geometry of the pond (Table 4). The water body below a depth of $8 \mathrm{~m}$ was found to be not directly affected by perturbations of the surface zone (Stottmeister et al. 2002; Stottmeister 2008). The longterm efficiency of auto-oxidation, polymerization, sedimentation and biodegradation caused the resulting concentration decrease of the organics inside the upper water layer. Additionally, the immobilized lowmolecular contaminants could be transferred into the deeper layer by precipitated organic particles. In this way, a natural sub-hydric deposition in the ground layer of the pond was formed. A forecast to 2030 showed no direct danger to the groundwater by the lake water. The phenol plume was unlikely to exceed a length of $250 \mathrm{~m}$ (Eccarius et al. 2001).

However, the results of the physicochemical analysis of the deposed water and the emissions of volatile phenolic compounds and hydrogen sulphide indicated a high potential of danger to the health of humans in nearby settlements, particularly in summer time. It was concluded that remediation was urgently necessary. At the time, no experience was available for treatment of a wastewater pond of this dimension and contaminant composition. Consequently, further investigations were necessary to evaluate the physicochemical and biological treatment possibilities in order to design and implement an efficient remediation strategy.

\subsection{Biological degradability and physicochemical removal of contaminants}

The aerobic and anaerobic microbial degradability of wastewater components were investigated in several laboratory-scale experiments (Wießner et al. 1994). Water from a depth of $24 \mathrm{~m}$ inoculated with different aerobically enriched bacterial cultures was treated in continuous mode in a laboratory-scale aerobic bioreactor (Fig. 3).

Firstly, the results suggested the potential for the aerobic microbial degradability of the organic load. Secondly, the extent of ammonium oxidation was estimated with nearly complete nitrification using related inoculates. Specifically, $50-70 \%$ of the totally 


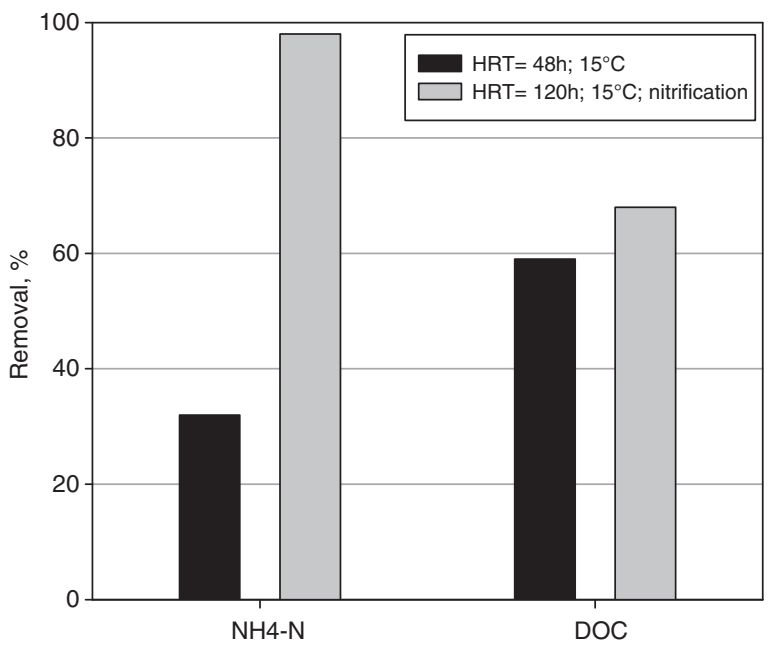

Fig. 3. Aerobic microbial degradability of water contaminants from a depth of $24 \mathrm{~m}$ of the wastewater disposal pond in a fermenter of continuous mode in dependence on the hydraulic retention time (HRT) at $15{ }^{\circ} \mathrm{C}$

removed DOC was found to be low-molecular compounds $(<0.5 \mathrm{kDa}), 8-13 \%$ were high-molecular compounds and colloid immobilized by the biomass, and $2-8 \%$ could be determined as transformed from the low molecular range to the range of predominantly $<0.5-5 \mathrm{kDa}$. Simultaneously, the water was decolorized by $30-60 \%$ as measured as changes in light absorption at a wave length of $436 \mathrm{~nm}$.

For querying the potential toxicity of the contaminants to anaerobic degradation, the influence of the deep water on the efficiency of an enrichment culture of acetoclastic methanogenic bacteria was measured (Fig. 4).

A nearly total inhibition of methanogenesis was observed when untreated deep water was used. In

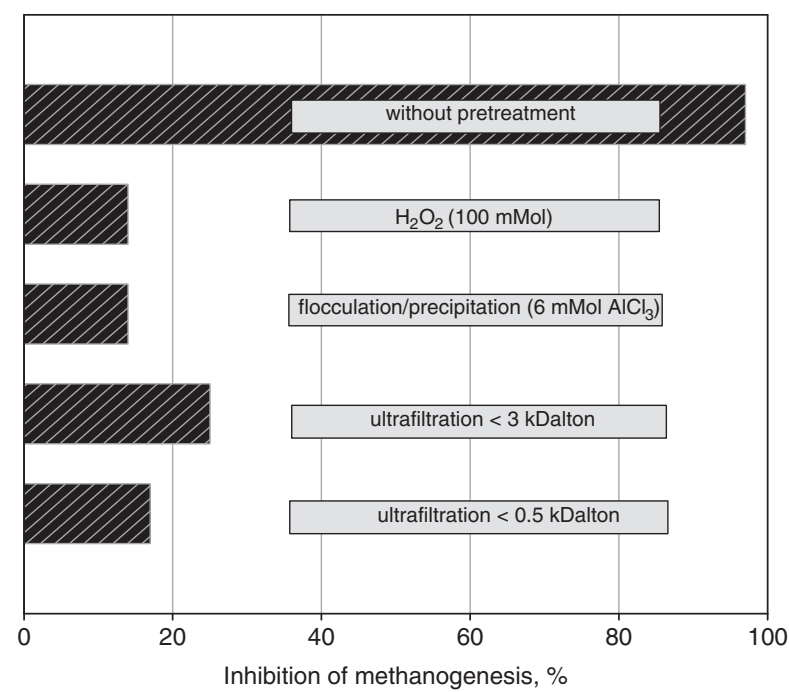

Fig. 4. Relative inhibition of methane formation of an acetoclastic methanogenic enrichment culture after different pre-treatments of water from a depth of $24 \mathrm{~m}$ of the wastewater disposal pond contrast, the removal of the high-molecular parts of the organics by physicochemical pre-treatment methods, such as $\mathrm{H}_{2} \mathrm{O}_{2}$-oxidation, flocculation/precipitation and ultrafiltration, enabled a highly efficient methanogenesis by the enrichment culture. These results were in accordance with previous findings investigating the toxicity by using the Photobacterium test indicating comparably high toxicity of high molecular autooxidation products of phenolic compounds. The most efficient transformation of organics by the methanogenic enrichment culture was found for deep water pretreated by ultrafiltration and flocculation/precipitation (Fig. 5). Accordingly, about $60 \%$ to more than $80 \%$ of the DOC were removed and transformed into methane. Additionally, all physicochemical pre-treatments improved the efficiency of decolorization of the deep brownish colored water (Table 6).

The main findings from these pre-investigations can be outlined as follows:

(1) The removal of high-molecular-weight, colloidal, and particulate organic contaminants was necessary for an enhanced biological degradation.

(2) High-molecular-weight, colloidal, and particulate organics can be removed efficiently by using physicochemical methods and

(3) low-molecular-weight organics were efficiently biodegraded using aerobic and anaerobic bacteria.

In addition, the efficiency of the wetland technology to treat the water of the disposal pond was evaluated. A pilot-scale subsurface horizontal-flow constructed wetland with an area of $125 \mathrm{~m}^{2}$ was established on the shore of the wastewater disposal

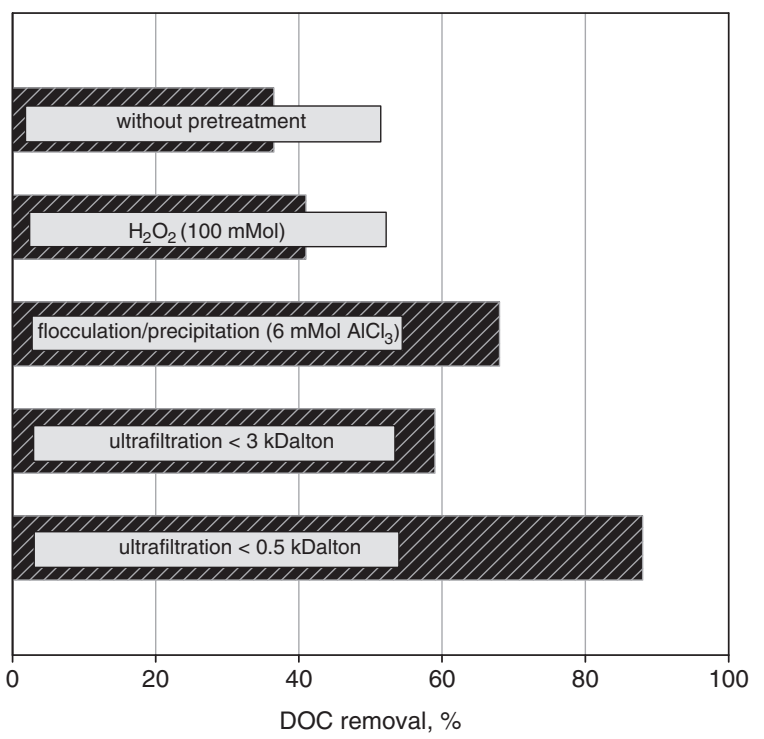

Fig. 5. The degradability of DOC of different pre-treated water from a depth of $24 \mathrm{~m}$ of the wastewater disposal pond in a methanogenic enrichment culture 
Table 6. Decolorization efficiencies of several physicochemical treatment methods of water from a depth of $24 \mathrm{~m}$ of the wastewater disposal pond (Wießner et al. 1994)

\begin{tabular}{lc}
\hline Method & $\begin{array}{c}\text { Decrease in light } \\
\text { absorption at a wave } \\
\text { length of } 436 \mathrm{~nm}(\%)\end{array}$ \\
\hline Ultrafiltration $(<3 \mathrm{kD})$ & 91.7 \\
Ultrafiltration $(<0.5 \mathrm{kD})$ & 98.2 \\
Oxidation with $\mathrm{H}_{2} \mathrm{O}_{2}(3.5 \%)$ & 93.3 \\
Flocculation/precipitation with $\mathrm{AlCl}_{3}$ & 99.2 \\
\hline
\end{tabular}

pond (Wießner et al. 1999; Kuschk et al. 2003). The constructed wetland was operated continuously for several years and its efficiencies for the removal of contaminants were determined.

The monitoring results suggest a long-term stable removal of nitrogen at high levels. Concerning ammonium-nitrogen, mean removal rates in the range of 0.51 to $0.59 \mathrm{~g} / \mathrm{m}^{2} \mathrm{~d}$ resulted in a $35-52 \%$ eliminating efficiency (Kuschk et al. 2003). Simultaneously, DOC was found to be removed by up to $47 \%$ (Wießner et al. 1999).

These results demonstrated that large-scale removal of ammonium-nitrogen in a subsurface horizontal-flow constructed wetland would be feasible. A constructed wetland with an area of 0.65 ha was considered necessary for continuous treatment of the water from the upper layer of the pond (Wießner et al. 1999). However, lack of suitable land close to the disposal pond prevented the construction of a sufficiently large treatment wetland.

\subsection{Remediation strategy and in situ pilot-scale investigations}

A particular remediation strategy for the disposal pond ensuring maximum treatment success with minimum expenditure and energy requirements had to be developed. Taking into account the depth distribution of the contaminants, the hydrodynamics of the pond, the results of the physicochemical and biological investigations and the land required for a treatment wetland, an in situ remediation strategy incorporating the principle of enhanced natural attenuation was developed. All stakeholders involved had to agree to this strategy.

The aim of the long-term strategy was to transform this meromictic disposal pond into a safe ecosystem containing the following two separate compartments:

(1) A subhydric deposition of contaminants in the undisturbed zone of the water body below a depth of approximately $8-10 \mathrm{~m}$ and
(2) a hydrodynamic water body in the depth of approximately $0-8 \mathrm{~m}$ free of high-molecularweight, colloidal, and particulate organics to be cleaned continuously over years by biological and chemical removal of the low-molecularweight contaminants (mainly organics and ammonium).

Firstly, it was concluded that a short-term initial treatment was necessary to facilitate the long-term strategy as follows:

(1) The physicochemical treatment of the water body to remove high-molecular-weight, colloidal, and particulate organics, and

(2) the initiation of microbiological activity to achieve long-term efficiency.

Secondly, flocculation/sedimentation was selected to be the most advantageous physicochemical method to remove the high-molecular-weight and aggregated organics considering all technological (amounts of treatment chemicals, procedures, efficiency) as well as economic (specific treatment costs) aspects of the decision. In particular, the following treatment steps were decided to be necessary:

(1) Flocculation using iron(III)-chloride at $\mathrm{pH} 4$ 5 , sedimentation of most of the high-molecular-weight organics into the bottom layer of the pond and

(2) the dosage of lime solution for neutralization of the pond water to $\mathrm{pH} \mathrm{7-7.5} \mathrm{and} \mathrm{the} \mathrm{dosage}$ of phosphate for nutrition, in order to enhance the activity of the inherent microbiota.

With the intention to test the efficiencies of in situ flocculation and sedimentation, the long-term stability of the resulting state and the influences of seasonal changes of water temperature and wind, a pilot-scale experiment was necessary prior to starting full-scale treatment of the disposal pond. An enclosure of $33 \mathrm{~m}$ in diameter and $25.5 \mathrm{~m}$ in depth (with a volume of about $20,000 \mathrm{~m}^{3}$ ) was placed at the deepest location almost in the centre of the disposal pond (Stottmeister 2008; Stottmeister et al. 2009). This artificial basin, which was completely separated from the surrounding water body, was filled with pond water from a depth of about $10 \mathrm{~m}$. Defined amounts of $\mathrm{FeCl}_{3}$ solution and lime suspension were added in succession and the main parameters such as DOC, transparency and watersteam-volatile phenols were observed over a total period of 700 days (Stottmeister et al. 2009). By this means, the DOC immediately decreased by about $50 \%$ and the $\mathrm{pH}$ was found to be adjusted to a value of 5 after introducing a dosage of the $\mathrm{FeCl}_{3}$ solution (Fig. 6). Simultaneously, the transparency increased 


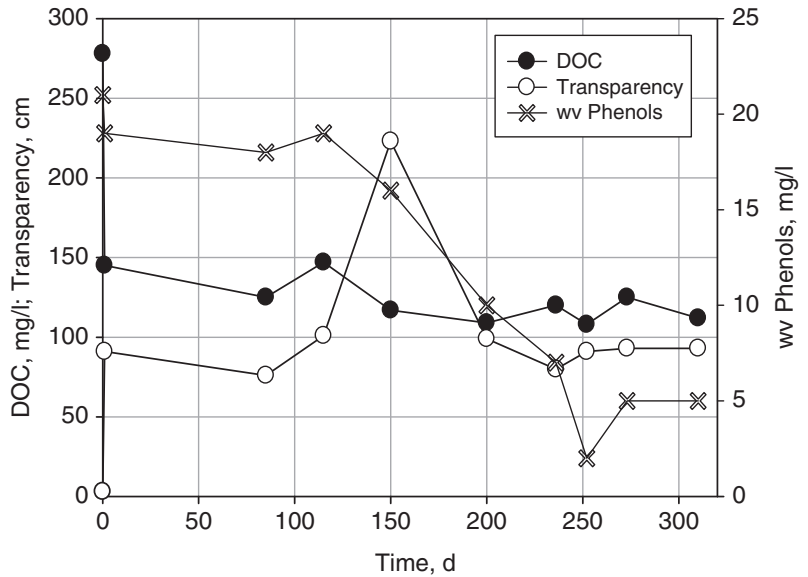

Fig. 6. Dynamics of DOC, watersteam-volatile (wv) phenols and transparency inside the pilot-scale in situ enclosure after flocculation on day zero (14-15 December 1994) and neutralization on days 80/81 (adapted from Stottmeister et al. 2009)

from the initial $3 \mathrm{~cm}$ to about $80 \mathrm{~cm}$ caused by the settling of the generated humate flocs.

During the following acidic phase of about three months winter time, an independent secondary flocculation was observed. On days 80 to 81 after flocculation, lime suspension was dosed to neutralize the water body at a $\mathrm{pH}$ of 7.5 (Stottmeister et al. 2009). Subsequently, the steam-volatile phenols decreased to a concentration of nearly $2 \mathrm{mg} / 1$ (from initially $21.5 \mathrm{mg} / \mathrm{l})$ simultaneously with the seasonal increase in water temperature. The transparency improved up to $2 \mathrm{~m}$, and in the upper layer of the enclosure, concentrations of about $1 \mathrm{mg} / \mathrm{l}$ of dissolved oxygen were measured. Furthermore, microbial degradation of several organic compounds such as phenols, cresols, xylenols and ethylphenols increased significantly only 5 months after the removal of the high-weight molecules, colloids and particulates. During the following period of approximately 450 days, the DOC decreased slowly but steadily, and the availability of low-molecularweight aromatic compounds, ammonium and oxygen was found to have enhanced the intensity of microbiological re-colonization after the initial decrease in bacterial numbers as a consequence of the iron (III) flocculation (Becker 1999; Becker et al. 1997, 1998; Becker, Stottmeister 1998; Stottmeister et al. 2002). Microbial activities were further enhanced by counteracting iron phosphate precipitation with additions of phosphoric acid $(75 \%, 1: 200$ dilution) to raise the mean phosphate concentration to about $1.4 \mathrm{mg} / \mathrm{l}$ inside the enclosure (Stottmeister et al. 2002).

The results and the experience of the enclosure experiment confirmed the treatment strategy in principal and encouraged the full-scale remediation of the disposal pond.

\subsection{Large-scale in situ treatment of the disposal pond and long-term remediation efficiency}

Based on the results of the laboratory-scale and enclosure experiments, the necessary concentrations and amounts of iron(III)-chloride, lime suspension and phosphoric acid for full-scale treatment of the disposal pond were determined, and operations started in October 1996 (Stottmeister et al. 2009). The acidic $\mathrm{FeCl}_{3}$ solution $\left(3200 \mathrm{~m}^{3} 40 \% \mathrm{FeCl}_{3}\right.$ ) was injected layer by layer into the disposal pond within a period of about 9 weeks using an engine-driven raft along a grid system (Stottmeister 2008; Stottmeister et al. 2002, 2009). The neutralization with $2200 \mathrm{~m}^{3}$ of $20 \%$ calcium carbonate suspension started in late April 1997 and was terminated at the end of August 1997. Phosphoric acid (three times $0.8 \mathrm{~m}^{3} 0.75 \%$ phosphoric acid) was added in April and August 1998 and once more in May of 1999. The first visible success of the remediation process was the increased transparency ranging from 60 to $200 \mathrm{~cm}$ depending on the season. At this treatment stage, the calculated 300 tons of macro-molecular humic-like organic material were precipitated. Simultaneously, large amounts of lowmolecular-weight contaminants from the upper parts of the water body were removed by adsorption to the high-weight molecules and the aggregated particles. The characteristic bad odor disappeared entirely, and the pond had attracted water birds.

The short-term and long-term efficiency of the remediation were evaluated by analyzing the characteristic contaminants and key parameters such as DOC, watersteam-volatile phenols and ammonium for different water depths (Stottmeister 2008; Stottmeister et al. 2009). The results of the investigations are presented in Figure 7.

Acidic flocculation and neutralization immediately affected all of the analyzed parameters. Accordingly, the DOC decreased very efficiently in all depths of the disposal pond, and the watersteam-volatile phenols and ammonium in the zones deeper than $5 \mathrm{~m}$ were found to be significantly removed up to the lower levels of the surface-near layers, as shown in Figure 6. During the next two years, the DOC slowly continued to decrease, the watersteam-volatile phenols completely disappeared from the water body, and the concentration of ammonium was found to have stabilized in the range of $80-120 \mathrm{mg} / \mathrm{l}$ at a depth below $10 \mathrm{~m}$ and to a level of about $50 \mathrm{mg} / \mathrm{l}$ at a depth of $5 \mathrm{~m}$. After these treatment steps, the targeted long-term stability of the meromictic stratification of the disposal pond was proven, most recently in 2008, 12 years after iron(III) flocculation. The concentrations of DOC and ammonium in the upper part of the disposal pond had decreased to levels of about 30 and $37 \mathrm{mg} / \mathrm{l}$, respectively. 


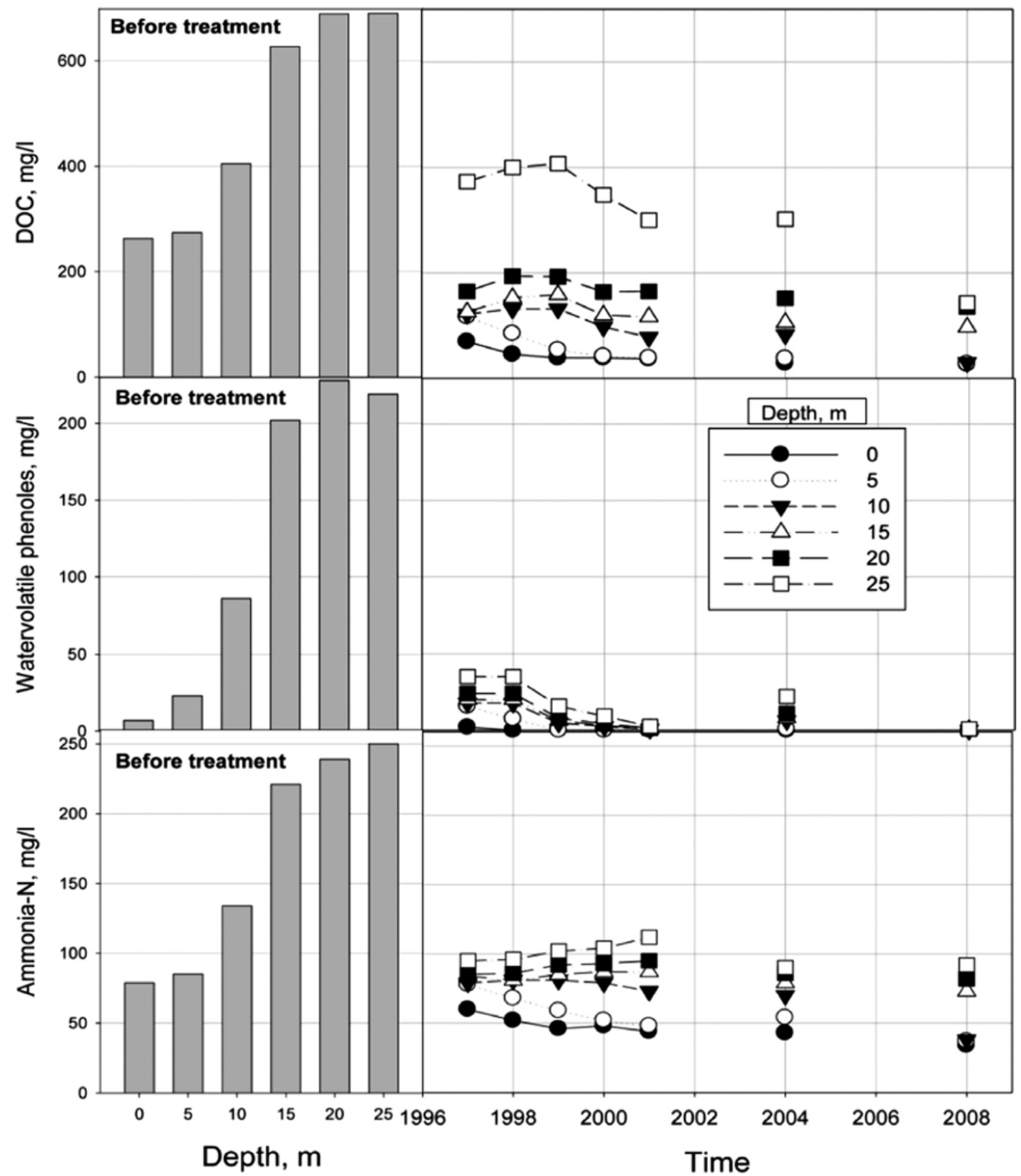

Fig. 7. DOC, watersteam-volatile phenols and ammonia-N before remediation and long-term monitoring of the parameters during and after the in-situ remediation of the disposal pond

In principle, a further long-term decrease of the contaminant concentrations can be postulated.

The dynamics of the different biological systems inside the pond were monitored during treatment and long-term remediation in addition to the physicalchemical analyses (Stottmeister et al. 2002). After neutralization, an enhanced growth of algae was observed. The density of bacteria and colorless flagellates increased as well, and the first multicellular organisms such as wheel animals (rotifers) were identified. Furthermore, the larvae of the mosquitoes
Culex sp. and Chironomidae sp. were found. The observed dominance of bacteria and heterotrophic flagellates is typical for humic-rich lakes and lakes highly loaded with organics from external sources (Stottmeister et al. 2002). During the period until the dosage of the phosphoric acid, the low microbial activity to remove pollutants was caused by phosphorous limitation. Dissolved oxygen could be measured to a depth of $2 \mathrm{~m}$ and the concentrations increased over time due to algae metabolisms and input from the air. However, because of the estimated lack of available 
phosphate $(>3 \mu \mathrm{g} / \mathrm{l})$, a rich plankton community did not develop despite oxygen availability and nutrition by bacteria and flagellates.

The dosage of phosphoric acid finally enhanced the growth of algae. In spring 1998, algae biomass was found to double daily from an initial $0.01 \mathrm{~mm}^{3} / 1$ before the phosphate dosage and finally to $77 \mathrm{~mm}^{3} / 1$ only one month later (Stottmeister et al. 2002). The oxygen concentration increased and the contaminant removal processes continued mainly by plankton metabolism and sorption.

The ongoing removal of pollutants during the next three years affected a nutrient decrease and the settlement of zooplankton such as ciliates (Halteria grandinella), wheel animals (Brachionus calyciflorus $f$. anuraeiformis) and cladocerans (Moina macrocopa and Daphnia pulex) (Stottmeister et al. 2002). The algae concentrations decreased simultaneously and a nearly fully developed food chain (except fish), including all trophic levels, was found to be established (Stottmeister et al. 2002). Finally, highly sensitive organisms such as the larvae of the top predator phantom midges (Chaoboridae) were observed in high densities, and algae almost disappeared completely.

\section{Conclusions}

1. Wastes from the carbo-chemical industry in Central Germany have been deposed off in open-cast mines or former industrial areas for many decades. The large scale of the contamination and the chemical composition of the wastes urgently required new and often casespecific methods for an economically sustainable remediation.

2. A highly toxic and dark-colored phenolic wastewater from a lignite pyrolysis factory was filled into a former open-cast pit, forming a wastewater disposal pond. This caused extensive environmental pollution, requiring an ecologically and economically acceptable strategy for remediation.

3. Laboratory-scale investigations and pilot-scale tests were necessary on the basis of an interdisciplinary cooperation between chemists, microbiologists, hydrologists, biologists and technologists.

4. A strategy for a full-scale enhanced in situ natural attenuation on the basis of separate habitats inside this meromictic pond was developed. A stable anaerobic layer in the depth, including an undisturbed subhydrical deposition with a low influence on the adjacent groundwater layer, and a biological dynamic upper layer to a depth of approximately $10 \mathrm{~m}$ was created.
5. Long-term monitoring of the chemical and biological dynamics of the pond shows the metamorphosis of a former highly polluted industrial waste deposition to a nature-integrated ecosystem with reduced danger for the environment.

\section{Acknowledgments}

The authors would like to thank E. Weissbrodt for the management of the project and her dedication as well as I. Richter and R. Schumann for technical assistance. The technical field work was financed and executed by the Lausitzer und Mitteldeutsche Bergbau-Verwaltungsgesellschaft $\mathrm{mbH}$ (LMBV). The authors are grateful to the staff of LMBV, and, in particular, they would like to thank W. Kletzander for the fruitful cooperation.

\section{References}

Baltrenas, P.; Kazlauskiene, A. 2009. Sustainable ecological development reducing negative effects of road maintenance salts, Technological and Economic Development of Economy 15: 178-188.

Becker, P. M. 1999. About the order in heterotrophic microbial communities from hydrocarbon contaminated sites, International Biodeterioration and Biodegradation 43: $135-146$. http://dx.doi.org/10.1016/S0964-8305(99)00042-6

Becker, P. M.; Stottmeister, U. 1998. General (Biolog GN) versus site-relevant (pollutant-dependent) sole-carbonsource utilization patterns as a means to approaching community functioning, Canadian Journal of Microbiology 44: 913-919. http://dx.doi.org/10.1139/w98-084

Becker, P. M.; Wand, H.; Martius, G. G. S.; Weissbrodt, E.; Stottmeister, U. 1998. Functional and structural successions in arbitrary samples of heterotrophic bacteria during aerobic treatments of lignite-carbonization wastewater in in-situ enclosures, Canadian Journal of Microbiology 44: 211-220. http://dx.doi.org/10.1016/S0045-6535(97)00001-5

Becker, P. M.; Wand, H.; Weißbrodt, E.; Kuschk, P.; Stottmeister, U. 1997. Distribution of contaminants and the self-purifying potential for aromatic compounds in a carbonization waste water deposit, Chemosphere 34: 731-748.

Bilkenroth, K.-D.; Snyder, D. O. 1998. Brown coal mining in Central Germany - history, presence, and future MIBRAG - Mitteldeutsche Braunkohlengesellschaft $m b H$, Theißen. Germany (in German).

Biswas, R.; Bagchi, S.; Urewar, C.; Gupta, D.; Nandy, T. 2010. Treatment of wastewater from a low-temperature carbonization process industry through biological and chemical oxidation processes for recycle/reuse: a case study, Water Science and Technology 61: 2563-2573. http://dx.doi.org/10.2166/wst.2010.181

Ciahotny, K.; Kusy, J.; Kolarova, L.; Safarova, M.; Andel, L. 2011. Brown coal and rape cakes copyrolysis, Chemicke Listy 105: 879-884.

Domazetis, G.; Barilla, P.; James, B. D. 2010. Lower emission plant using processed low-rank coals, Fuel Processing 
Technology 91: 255-265.

http://dx.doi.org/10.1016/j.fuproc.2009.10.006

Eccarius, B. 1998. Groundwater monitoring and isotope investigation of contaminated wastewater from an open pit mining lake, Environmental Geosciences 5: 156-161. http://dx.doi.org/10.1046/j.1526-0984.1998.08022.x

Eccarius, B.; Christoph, G.; Ebhardt, G.; Gläßer, W. 2001. Grundwassermodellierung zur Gefährdungsabschätzung eines phenolverseuchten Tagebaurestsees [Groundwater modelling for risk assessment of a phenol contaminated open pit mining lake], Grundwasser 2: 61-70 (in German). http://dx.doi.org/10.1007/PL00010392

Eissmann, L. 1994. From the earth-archives of Central Germany. Beucha, Germany: Sax-Verlag.

Folgueras, M. B.; Diaz, R. M. 2010. Influence of $\mathrm{FeCl}_{3}$ and lime added to sludge-coal pyrolysis, Energy 35: 52505259. http://dx.doi.org/10.1016/j.energy.2010.07.040

Garg, A.; Mishra, I. M.; Chand, S. 2008. Catalytic oxidative treatment of diluted black liquor at mild conditions using copper oxide cerium oxide catalyst, Water Environment Research 80: 136-141. http://dx.doi.org/10.2175/106143007X220752

Huang, L. P.; Yang, X. H.; Quan, X.; Chen, J. W.; Yang, F. L. 2010. A microbial fuel cell-electro-oxidation system for coking wastewater treatment and bioelectricity generation, Journal of Chemical Technology and Biotechnology 85: 621-627. http://dx.doi.org/10.1002/jctb.2320

Kopinke, F.-D.; Pörschmann, J.; Remmler, M. 1995a. Sorption behavior of anthropogenic humic matter, Naturwissenschaften 82: 28-30. http://dx.doi.org/10.1007/BF01167866

Kopinke, F.-D.; Pörschmann, J.; Stottmeister, U. 1995b. Sorption of organic pollutants on anthropogenic humic matter, Environmental Science \& Technology 29: 941-950. http://dx.doi.org/10.1021/es00004a014

Kubal, M.; Podhola, M.; Patocka, T.; Ciahotny, K.; Kuras, M. 2011. Treatment of ammonia-polluted groundwater in North Bohemian brown coal mining region - Feasibility study, Desalination and Water Treatment 33: 36-43. http://dx.doi.org/10.5004/dwt.2011.2616

Kuschk, P.; Stottmeister, U.; Liu, Y.-J.; Wiessner, A.; Kästner, M.; Müller, R.-A. 2010. Batch methanogenic fermentation experiments of wastewater from a brown coal low-temperature coke plant, Journal of Environmental Sciences 22: 192-197. http://dx.doi.org/10.1016/S1001-0742(09)60092-9

Kuschk, P.; Wießner, A.; Kappelmeyer, U.; Weißbrodt, E.; Kästner, M.; Stottmeister, U. 2003. Annual cycle of nitrogen removal by a pilot-scale subsurface horizontal flow in a constructed wetland under moderate climate, Water Research 37: 4236-4242. http://dx.doi.org/10.1016/S0043-1354(03)00163-5

Kuschk, P.; Wießner, A.; Martius, G.; Weißbrodt, E.; Stottmeister, U. 1994. Untersuchungen zur Sanierung wäßriger Altlasten der Braunkohlepyrolyseindustrie [Investigations on remediation of wastewaters from lignite pyrolysis industries], Energieanwendung, Energie- und Umwelttechnik 43: 309-312 (in German).
Mackenzie, K.; Georgi, A.; Kumke, M.; Kopinke, F.-D. 2002. Sorption of pyrene to dissolved humic substances and related model polymers. 2. Solid-phase microextraction (SPME) and fluorescence quenching technique (FQT) as analytical methods, Environmental Science \& Technology 36: 4403-4409. http://dx.doi.org/10.1021/es010310x

Mursito, A. T.; Hirajima, T.; Sasaki, K.; Kumagai, S. 2010. The effect of hydrothermal dewatering of Pontianak tropical peat on organics in wastewater and gaseous products, Fuel 89: 3934-3942. http://dx.doi.org/10.1016/j.fuel.2010.06.035

Pathiratne, K. A. S.; De Silva, O. C. P.; Hehemann, D.; Atkinson, I.; Wei, R. 2007. Occurrence and distribution of polycyclic aromatic hydrocarbons (PAHs) in Bolgoda and Beira Lakes, Sri Lanka, Bulletin of Environmental Contamination and Toxicology 79: 135-140. http://dx.doi.org/10.1007/s00128-007-9092-z

Pörschmann, J.; Kopinke, F.-D.; Balcke, G.; Mothes, S. 1998a. Pyrolysis pattern of anthropogenic and natural humic organic matter, Journal of Microcolumn Separations 10: $401-411$. http://dx.doi.org/10.1002/(SICI)1520-667X(1998)10:5< 401::AID-MCS3 > 3.0.CO;2-K

Pörschmann, J.; Kopinke, F.-D.; Pawliszyn, J. 1998b. Solidphase microextraction for determining the binding state of organic pollutants in contaminated water rich in humic organic matter, Journal of Chromatography A 816: 159-167. http://dx.doi.org/10.1016/S0021-9673(98)00525-1

Pörschmann, J.; Kopinke, F.-D.; Remmler, M.; Mackenzie, K.; Geyer, W.; Mothes, S. 1996. Hyphenated techniques for characterizing coal wastewaters and associated sediments, Journal of Chromatography A 750: 287-301. http://dx.doi.org/10.1016/0021-9673(96)00403-7

Pörschmann, J.; Stottmeister, U. 1993. Methodical investigation of interaction between organic pollutants and humic organic material in coal wastewaters, Chromatographia 36: 207-211. http://dx.doi.org/10.1007/BF02263865

Pörschmann, J.; Zhang, Z.; Kopinke, F.-D.; Pawliszyn, J. 1997. Solid phase microextraction for determining the distribution of chemicals in aqueous matrices, Analytical Chemistry 69: 597-600. http://dx.doi.org/10.1021/ac9609788

Qi, W. X.; Liu, H. J.; Qu, J. H.; Hu, C. Z.; Lan, H. C.; Berg, M.; Ren, H. M.; Xu, W. 2011. Polycyclic aromatic hydrocarbons in effluents from wastewater treatment plants and receiving streams in Tianjin, China, Environmental Monitoring and Assessment 177: 467-480. http://dx.doi.org/10.1007/s10661-010-1648-4

Ringpfeil, M.; Stottmeister, U.; Behrens, U.; Martius, G.; Bürger, G.; Wenige, L. 1988. Aerobic treatment of sewage from lignite (brown coal) processing, in Wise, D. L. (Ed.). Biotreatment Systems. Boca Raton, Florida: CRC Press.

Stottmeister, U. 2008. Altlastensanierung mit Huminstoffsystemen [Remediation of wastes from the past using humic substances]. Chemie in unserer Zeit 42: 24-41 (in German). http://dx.doi.org/10.1002/ciuz.200800439

Stottmeister, U.; Glässer, W.; Klapper, H.; Weissbrodt, E.; Eccarius, B.; Kennedy, C.; Schultze, M.; Wendt-Potthoff, K.; Frömmichen, R.; Schreck, P.; Strauch, G. 1999. Strategies 
for remediation of former opencast mining areas in eastern Germany, in Azcue, J. M. (Ed.). Environmental Impacts of Mining Activities: Emphasis on Mitigation and Remediation. Berlin, Heidelberg, New York: SpringerVerlag, 263-296. http://dx.doi.org/10.1007/978-3-642-59891-3_16

Stottmeister, U.; Kuschk, P.; Wießner, A. 2009. Full-scale bioremediation and long-term monitoring of a phenolic wastewater disposal lake, Pure \& Applied Chemistry 82: 161-173. http://dx.doi.org/10.1351/PAC-CON-09-05-05

Stottmeister, U.; Kuschk, P.; Wießner, A.; Weißbrodt, E.; Martius, G.; Becker, P. M.; Eismann, F.; Kotte, H. 1997. Altlastenprobleme der Carbochemie in Nordwestsachsen: Entstehung, Ausmaß und erste Sanierungskonzepte [Wastes from the past of the carbo-chemistry in North-Western Saxony: formation, size, and first remediation strategies], in Knorr, C.; Schell, T. (Eds.). Mikrobieller Schadstoffabbau. Braunschweig, Wiesbaden, Germany: Vieweg, 357-375 (in German).

Stottmeister, U.; Weißbrodt, E.; Becker, P. M.; Pörschmann, J.; Kopinke, F.-D.; Martius, G. G. M.; Wießner, A.; Kennedy, C. 1998. Analysis, behaviour and fate of a lignite pyrolysis wastewater deposit, in Contaminated Soil 98, Sixth International FZK/TNO Conference on Contaminated Soil. London: Thomas Telford Publishing, 113-121.

Stottmeister, U.; Weißbrodt, E.; Tittel, J. 2002. From contamination of the past to a lake [Von der Altlast zum See], Biologie in unserer Zeit 32: 276-285. http://dx.doi.org/10.1002/1521-415X(200209)32:5 <276:: AID-BIUZ276 > 3.0.CO;2-G

Thiruvenkatachari, R.; Younes, M.; Su, S. 2011. Coal mine site investigation of wastewater quality in Australia, Desalinations and Water Treatment 32: 357-364. http://dx.doi.org/10.5004/dwt.2011.2722

Tokarska, A. 2009. Preliminary studies on brown coals liquefaction, Rocznik Ochrona Srodowiska 11: 1095-1104.

Tomei, M. C.; Annesini, M. C. 2008. Biodegradation of phenolic mixtures in a sequencing batch reactor - a kinetic study, Environmental Science and Pollution Research 15: 188-195. http://dx.doi.org/10.1065/espr2007.12.470

Valentukeviciene, M.; Ignatavicius, G. 2011. Analysis and evaluation of the effect of the solids from road surface runoff on the sediments of river bed, Ekologija 57: 39-45. http://dx.doi.org/10.6001/ekologija.v57i1.1308
Volkmann, N.; Borner, K. 2012. The Deutsches Energie Rohstoff-Zentrum Freiberg: advanced prospects for applied organic petrology, focused on the generation of coal based chemical products, International Journal of Oil, Gas and Coal Technology 5: 399-409. http://dx.doi.org/10.1504/IJOGCT.2012.048984

Wießner, A.; Kuschk, P.; Martius, G.; Eismann, F.; Zehnsdorf, A.; Weißbrodt, E.; Stottmeister, U. 1994. Abbaubarkeit von Schadstoffen im BraunkohlepyrolyseAltwasser [Degradability of contaminants in disposed wastewater from lignite pyrolysis], Wasser Abwasser Praxis 4: 44-47 (in German).

Wießner, A.; Kuschk, P.; Stottmeister, U.; Struckmann, D.; Jank, M. 1999. Treating a lignite pyrolysis wastewater in a constructed subsurface flow wetland, Water Research 33: $1296-1302$. http://dx.doi.org/10.1016/S0043-1354(98)00310-8

Wießner, A.; Kuschk, P.; Weißbrodt, E.; Stottmeister, U.; Pörschmann, J.; Kopinke, F.-D. 1993. Charakterisierung des Wassers und des Sedimentes einer BraunkohleSchwelwasserdeponie [Characterization of the water and the sediment of a wastewater disposal from lignite pyrolysis], Wasser Abwasser Praxis 6: 375-379 (in German).

Wu, Y. B.; Fu, J.; Zeng, S. S.; Sun, P.; Yan, Y. C. 2012. A thermal analysis calculation of pharmaceutical wastewater sludge, Journal of Thermal Analysis and Calorimetry 108: 389-395. http://dx.doi.org/10.1007/s10973-011-1683-6

Xu, Z. X.; Wei, Z.; Yin, H. L.; Huang, L. H. 2010. Optimized design of natural ecological wastewater treatment system based on water environment model of dynamic mesh technique, Journal of Hydrodynamics 22: 1-8. http://dx.doi.org/10.1016/S1001-6058(09)60021-4

Zhang, Y. M.; Bao, S. X.; Liu, T.; Chen, T. J.; Huang, J. 2011. The technology of extracting vanadium from stone coal in China: History, current status and future prospects, Hydrometallurgy 199: 116-124. http://dx.doi.org/10.1016/j.hydromet.2011.06.002

Zhou, L.; Hu, S. Y.; Li, Y. R.; Jin, Y.; Zhang, X. L. 2012. Modeling and optimization of a coal-chemical ecoindustrial system in China, Journal of Industrial Ecology 16: $105-118$. http://dx.doi.org/10.1111/j.1530-9290.2012.00447.x transformation of organic pollutants, genomics of sulphur-oxidizing bacteria.

Peter KUSCHK. Dr, head of the group of Ecological Water Treatment Technologies, PhD (1991), 68 publications indexed in the ISI Web of Science. Research interests: microbial anaerobic processes in constructed wetlands, hygienization of domestic sewage.

Uwe KAPPELMEYER. Dr, research engineer, PhD (2001), 14 publications indexed in the ISI Web of Science. Research interests: molecular biological techniques for the characterization of microbial cenoses, simulation of biotechnological processes.

Matthias KÄSTNER. Professor, head of the Department of Environmental Biotechnology, PhD (1989), more than 100 publications indexed in the ISI Web of Science. Research interests: bioremediation processes, metabolic flow in environmental systems, C and $\mathrm{N}$ turnover in soil, genesis of soil organic matter. 
Yong-Jun LIU. Professor, head of the group of Biological Wastewater Treatment Technologies, PhD (2004), 21 publications indexed in the ISI Web of Science. Research interests: bioremediation of environmental pollution, characterization of biological toxic effects for environmental pollutants.

Ulrich STOTTMEISTER. Professor emeritus, PhD (1968), 71 publications indexed in the ISI Web of Science. Research interests: technology assessment, biological wastewater treatment, microbial product formation. 